\title{
Pooled data analysis on anterior versus posterior approach for rheumatoid arthritis at the craniovertebral junction
}

\author{
Lee Onn Chieng, BS, Karthik Madhavan, MD, and Steven Vanni, DO \\ Department of Neurological Surgery, University of Miami Miller School of Medicine, Miami, Florida
}

\begin{abstract}
OBJECT Rheumatoid arthritis (RA) is one of the most debilitating autoimmune diseases affecting the craniovertebral junction (CVJ). Patients predominantly present with myelopathic symptoms and intractable neck pain. The surgical approach traditionally has been either a combined anterior and posterior approach or a posterior-only approach. In this article, the authors review pooled data from the literature and discuss the benefits of the two types of approaches.
\end{abstract}

METHODS A search of the PubMed database was conducted using key words that describe spine deformities in RA and specific spinal interventions. The authors evaluated the neurological outcomes based on the Ranawat scale in both the groups through chi-square analysis. Multiple logistic regression was carried out to further examine for potential confounders. Any adverse sequalae resulting from either approach were also documented. Because all the procedures performed via a transoral approach in the analyzed articles also involved posterior fixation, for convenience of comparison, the combined procedures are referred to as "anterior approach" or "anterior-posterior" in the present study.

RESULTS The search yielded 233 articles, of which 11 described anterior approaches and 14 evaluated posterior approaches. The statistical analysis showed that patients treated with a posterior approach fared better than those treated with an anterior (combined) approach. It was noted that those patients in whom the cervical subluxations were reducible on traction predominantly underwent posterior approaches.

CONCLUSIONS CVJ instability is a serious complication of RA that requires surgical intervention. Although the anterior-posterior combined approach can provide direct decompression, it is associated with morbidity, and the analysis showed no statistically significant benefit to patients. In contrast, the posterior approach has been shown to provide statistically significant superiority with respect to stabilization and subsequent pannus reduction. Surgical approaches are undertaken based on the reducibility of subluxations with traction and the vector of compressive force. However, the choice of surgical approach should be based on the individual patient's pathology.

http://thejns.org/doi/abs/10.3171/2015.1.FOCUS14838

KEY WORDS atlantoaxial subluxation; cranial settling; basilar invagination; rheumatoid arthritis

$\mathrm{R}$ HEUMATOID arthritis (RA) is a debilitating systemic autoimmune disease that predominantly affects synovial joints. Craniovertebral junction (CVJ) involvement is seen in $36 \%-88 \%$ of patients. ${ }^{1,2,4,13,22,32,40}$ The pathophysiology of the inflammatory disorder often starts with synovitis, followed by formation of a pannus, which is characterized by inflammatory infiltrate (T cells, $\mathrm{B}$ cells, and cytokines) and digestive enzymes (matrix metalloproteinases, collegenases). Given the erosive and bulky nature of the pannus and its dangerous location at $\mathrm{CVJ}$, the probability of potential fatal complications such as cervical spine instability, blockage of vertebral arteries, and direct spinal cord compression is likely to increase as the disease progresses. A number of spinal deformities have been associated with RA. Atlantoaxial (C1-2) instability is the most common clinical manifestation, and it may lead to atlantoaxial subluxation or basilar invagination/cranial settling.

ABBREVIATIONS AADI = anterior atlantodental interval; $C V J=$ craniovertebral junction; $P A D I=$ posterior atlantodental interval; $\mathrm{RA}=$ rheumatoid arthritis.

SUBMITTED December 1, 2014. ACCEPTED January 27, 2015.

INCLUDE WHEN CITING DOI: 10.3171/2015.1.FOCUS14838.

DISCLOSURE The authors report no conflict of interest concerning the materials or methods used in this study or the findings specified in this paper. 
Spinal surgery is often indicated when patients present with intractable neck pain or progressive neurological symptoms. The surgical procedures are generally categorized into two groups: 1) combined anterior and posterior approaches and 2) posterior-only approach. The principle behind the anterior approach is to achieve direct decompression of the anterior cervical pathology, and the goal of the posterior approach is to stabilize the alignment of the vertebral column with immobilization to reduce pannus formation. ${ }^{14}$ Direct decompression via C-1 laminectomy may also be carried out if the vector of pressure is greater posteriorly. To date, there is no general consensus on which approach is the best for patients with RA. In this review, we aim to provide an overview of different spinal interventions and attempt to derive a surgical management algorithm that is tailored specifically to rheumatoid abnormalities at the CVJ.

\section{Methods}

A comprehensive search of the English-language literature for the years 1975-2014 was performed on PubMed using combinations of the following phrases that describe spine deformities ("atlantoaxial subluxation", "basilar invagination", "cranial settling", "subaxial subluxation", "rheumatoid arthritis") and spinal interventions ("spine surgery", " anterior approach", "posterior approach, transoral", "fusion", "fixation"). Additional articles were located by cross-referencing articles encountered initially through the PubMed searches. Each index article was analyzed in detail, specifically focusing on the clinical outcome following either anterior or posterior approach. Since all the transoral procedures being done were complemented with posterior fixation, the combined approach is referred to in this paper, for convenience of comparison, as "anterior approach" or "anterior-posterior approach." Inclusion criteria comprised articles (case reports, case series, meta-analyses, clinical trials, literature reviews, molecular studies, animal models, and guidelines) originating from peer-reviewed literature and discussing the surgical management, outcomes, and complications of RA at the CVJ. Analyses were performed with SPSS 22.0 software. A chi-square test was used in simple comparison of approaches (anterior vs posterior) with respect to neurological outcome, while multivariate logistic regression was performed to assess the influence of confounding factors.

\section{Results \\ Study Selection}

Our PubMed search yielded 233 articles for screening and with the application of our inclusion criteria we narrowed the results to 25 articles (11 primarily on combined anterior-posterior approach and 14 on posterior-only approach). Of these 25 articles, 17 met the criteria for inclusion in our pooled data analysis. The detailed study selection flowchart is shown in Fig. 1.

\section{Study Characteristics}

The 11 combined anterior-posterior approach manuscripts included 674 patients (Table 1) and the 14 posterior-

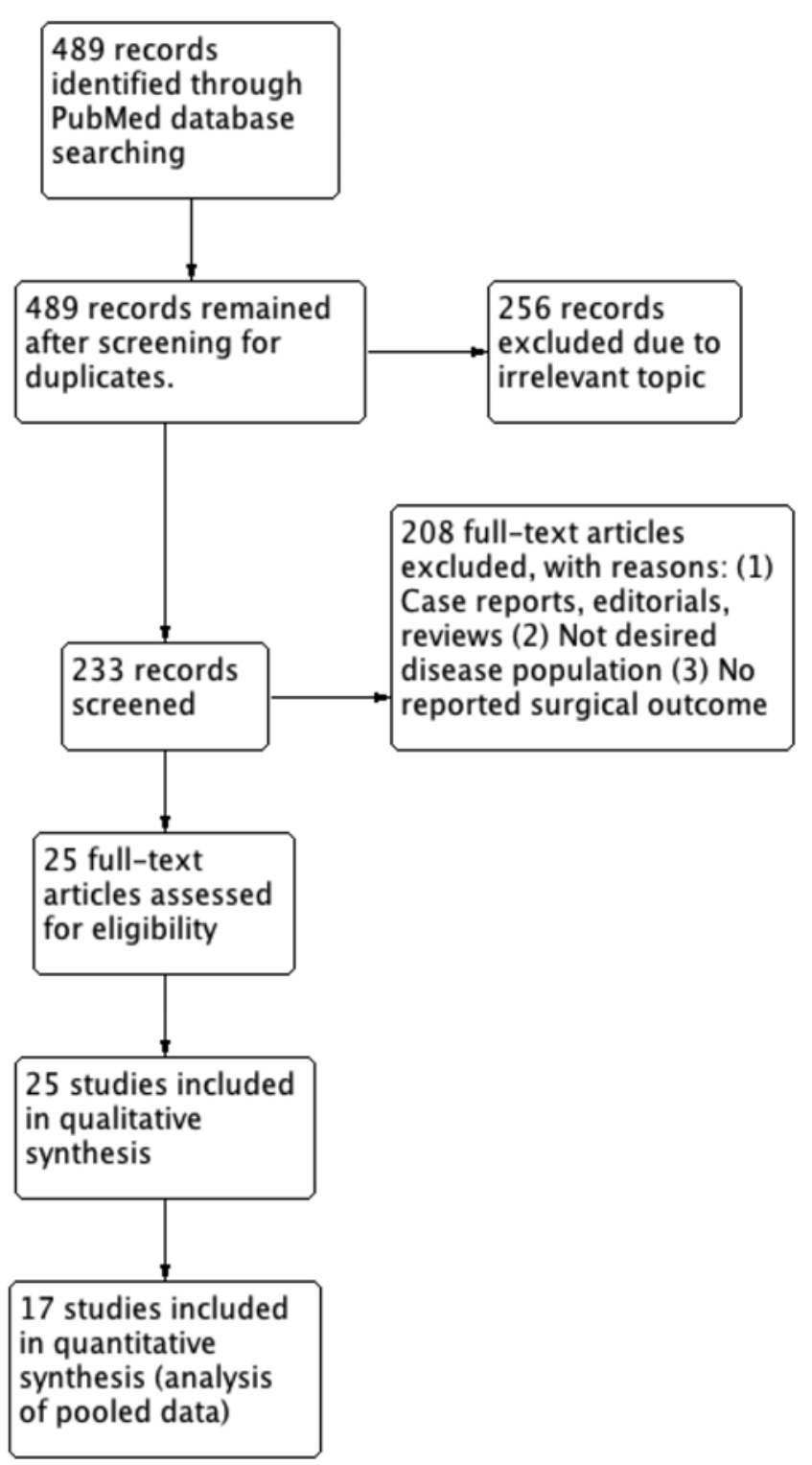

FIG. 1. Flow diagram representing the search criteria for selecting the articles. Out of 489 articles identified in the PubMed database and evaluated for this study, only 17 met the criteria for inclusion in the pooled data analysis.

only manuscripts included 592 patients (Table 2). Anterior approaches consisted primarily of transoral approaches while posterior approaches comprised occipitocervical, atlantoaxial, and subaxial fusion with laminectomy. The transoral approach was always supplemented with posterior fixation in the studies included in this analysis. For the convenience of categorizing the approaches, the combined anterior-posterior approach will be referred as "anterior approach" and posterior-only fusion as "posterior approach" for the rest of the paper.

\section{Neurological Outcome}

Neurological outcome was assessed based on the Ranawat classification. Improvement in neurological outcome was defined as improvement of at least 1 Ranawat 
TABLE 1. Characteristics of studies describing an anterior approach*

\begin{tabular}{|c|c|c|c|c|c|c|c|}
\hline Authors \& Year & Type of Study & $\begin{array}{l}\text { No. of } \\
\text { Pts }\end{array}$ & $\begin{array}{l}\text { Mean Age in Yrs } \\
\quad \text { (range) }\end{array}$ & $\begin{array}{l}\text { Female/ } \\
\text { Male }\end{array}$ & $\begin{array}{l}\text { FU } \\
\text { (mos) }\end{array}$ & Type of Surgery† & Diagnosis \\
\hline Menezes et al., 1985 & Retrospective & 45 & - & - & - & $\begin{array}{l}\text { Transoral in 7; poste- } \\
\quad \text { rior fixation in } 38\end{array}$ & BI, AAS, SAS \\
\hline Crockard et al., 1986 & Retrospective & 14 & $57.8(19-78)$ & $11: 3$ & 18 & Transoral & AAS \\
\hline Spetzler et al., 1988 & Retrospective & 13 & - & - & - & Transoral & $\mathrm{BI}$ \\
\hline Hadley et al., 1989 & Retrospective & 21 & 54 & - & 24 & Transoral & $\mathrm{Bl}$ \\
\hline Crockard et al., 1990 & Retrospective & 68 & - & - & - & Transoral & AAS \\
\hline Casey et al., $19966 \ddagger$ & Prospective & 134 & $62.9(22-82)$ & $110: 24$ & - & $\begin{array}{l}\text { Transoral in 91; poste- } \\
\text { rior fixation in } 43\end{array}$ & $\mathrm{BI}$ \\
\hline Casey et al., $19965 \ddagger$ & Prospective & 55 & 64.7 & $44: 11$ & - & $\begin{array}{l}\text { Transoral \& posterior } \\
\quad \text { fixation }\end{array}$ & $\mathrm{Bl}$ \\
\hline Casey et al., $1997 \ddagger$ & Prospective & 116 & $62.3(60.6-63.9)$ & $92: 24$ & 45.3 & $\begin{array}{l}\text { Transoral in } 67 \text {; poste- } \\
\text { rior fixation in } 49\end{array}$ & BI (71 irreducible) \\
\hline $\begin{array}{l}\text { Kerschbaumer et al, } \\
2000\end{array}$ & Retrospective & 15 & $61.6(31-82)$ & $12: 3$ & 50.7 & Transoral & $\begin{array}{l}\text { BI in } 8 \text { (coexisting pannus in } 3 \text {; } \\
\text { ondontoid fracture in 1); pannus } \\
\text { compression in } 5 \text { (coexisting } \\
\text { pannus compression in 1); } \\
\text { odontoid fracture alone in } 1\end{array}$ \\
\hline $\begin{array}{l}\text { Nannapaneni et al., } \\
2005\end{array}$ & Retrospective & 32 & $66.81(36-85)$ & $25: 7$ & 39 & $\begin{array}{l}\text { Transoral in 21; poste- } \\
\text { rior fixation in } 11\end{array}$ & $\begin{array}{l}\text { AAS (coexisting BI in 6; BI \& SAS } \\
\text { in } 3 \text {; SAS in } 5 \text { ) }\end{array}$ \\
\hline $\begin{array}{l}\text { Choi \& Crockard, } \\
2013\end{array}$ & $\begin{array}{l}\text { Retrospective \& } \\
\text { prospective }\end{array}$ & $\begin{array}{r}533(216 \\
\text { w/ RA) }\end{array}$ & 46.3 & $43 \%: 57 \%$ & 62.1 & Transoral & $\begin{array}{l}\mathrm{BI} \text {, congenital malformation, } \\
\text { chordoma }\end{array}$ \\
\hline
\end{tabular}

AAS = atlantoaxial subluxation; $\mathrm{BI}=$ basilar invagination; $\mathrm{FU}=$ follow-up; pts = patients; $\mathrm{SAS}=$ subaxial subluxation; - = data unavailable.

* Gray shading indicates studies that were included in the pooled data analysis.

$\dagger$ The transoral approach was always supplemented with posterior fixation in the studies included in this analysis.

$\ddagger$ Similar studies by same authors and based on same database.

class above the preoperative assessment. Among the 25 articles that discussed the use of anterior or posterior approaches, 4 anterior approach articles and 11 posterior approach articles reported Ranawat classification data; $68 \%$ of patients treated with an anterior approach demonstrated neurological improvement, whereas $98 \%$ of patients treated with a posterior approach showed neurological improvement. When anterior versus posterior approach was the sole factor considered, the odds ratio for neurological improvement was 0.579 (95\% CI 0.379-0.886) as summarized in Fig. 2. In our multivariate analysis, when anterior versus posterior approach was adjusted for factors such as sex, mean age, preoperative neurological status, and length of follow-up, there was no significant correlation with neurological outcome. The pooled data describing the percent change in postoperative Ranawat classification from preoperative Ranawat classification were also analyzed, as shown in Figs. 3 and 4.

Complications following an anterior or a posterior approach are described in Table 3 and Table 4, respectively.

\section{Nonsurgical Predictors of Neurological Improvement}

Several preoperative factors, including sex, use of corticosteroids, and duration of myelopathy, were found to be not strongly associated with outcome. ${ }^{30,33}$ In our review, a multivariate analysis of the effect of age, sex, surgical technique, and follow-up period was performed to analyze the influence of these factors on neurological improvement (Table 5). Despite the significant finding in the pre- vious univariate analysis, we found that the surgical techniques were no longer significantly correlated with outcome when the mentioned factors were added. This was probably due to the smaller sample size $(n=121)$ available for the analysis and possible influence of confounding factors. Interestingly, sex and follow-up period were found to be potential confounders. Female sex had a significant effect on neurological outcome $(\mathrm{p}=0.001)$. It is well known that female sex is associated with a higher susceptibility to most autoimmune diseases, including RA. Meanwhile, it is logical that the longer the follow-up, the greater the chance for recovery in terms of neurological status $(\mathrm{p}=$ $0.003)$.

In consideration of demographic factors, elderly age is significantly correlated with poor outcome., ${ }^{5,34}$ This should prompt careful selection of elderly surgical candidates and also might suggest the beneficial effect of early surgical intervention. On the other hand, high Ranawat class, especially Class IIIB (with long tract dysfunction) typically is associated with slow recovery and a high mortality rate. ${ }^{33,34}$ Casey et al., ${ }^{5}$ in their multivariate analysis, demonstrated a high predictive value of preoperative spinal cord cross-sectional area for improvement of neurological outcome $(p=0.026)$. In other words, the smaller the spinal cord cross-sectional area, the worse the outcome. The spinal cord atrophy due to chronic compression and trauma most likely explains this observed phenomenon. Indeed, this led to more investigations focusing on different radiographic parameters: anterior atlantodental inter- 
TABLE 2. Characteristics of studies describing a posterior approach*

\begin{tabular}{|c|c|c|c|c|c|c|c|}
\hline Authors \& Year & Type of Study & $\begin{array}{l}\text { No. } \\
\text { of } \\
\text { Pts }\end{array}$ & $\begin{array}{l}\text { Mean Age in } \\
\text { Yrs (range) }\end{array}$ & $\begin{array}{l}\text { Female/ } \\
\text { Male }\end{array}$ & $\mathrm{FU}$ (mos) & Type of Surgery & Diagnosis \\
\hline Ranawat et al., 1979 & Retrospective & 33 & $62(42-85)$ & $21: 12$ & $54(12-96)$ & $\begin{array}{l}\text { Posterior fusion (occipitocervical in } \\
\text { 12; atlantoaxial in 13); anterior } \\
\text { fusion in } 5\end{array}$ & $\begin{array}{l}\text { AAS in } 13 ; \mathrm{BI} \text { in } 1 \text {; SAS } \\
\text { in } 7 \text {; AAS \& SAS in } 7 \\
\text { SAS \& BI in } 3\end{array}$ \\
\hline $\begin{array}{l}\text { Thompson \& Meyer, } \\
1985\end{array}$ & Retrospective & 12 & $53(25-68)$ & $10: 2$ & $36(7-84)$ & $\begin{array}{l}\text { Posterior fusion (occipitocervical in } \\
\text { 2; atlantoaxial in 10) }\end{array}$ & AAS \\
\hline $\begin{array}{l}\text { Larsson \& Toolanen, } \\
\quad 1986\end{array}$ & Retrospective & 34 & $54(29-72)$ & $20: 9$ & 36 & $\begin{array}{l}\text { Posterior fusion (occipitocervical in } \\
\text { 6; atlantoaxial in 28) }\end{array}$ & AAS in $28 ; \mathrm{BI}$ in 6 \\
\hline Clark et al., 1989 & Retrospective & 41 & $57(34-82)$ & $36: 5$ & $40(23-74)$ & $\begin{array}{l}\text { Posterior fusion (occipitocervical in } \\
\text { 16; atlantoaxial in 20); transoral in } \\
\text { 2; anterior cervical vertebrectomy } \\
\text { in } 1\end{array}$ & $\begin{array}{l}\text { AAS in } 20 \text {; } B \text { I in } 5 \text {; SAS } \\
\text { in } 4\end{array}$ \\
\hline $\begin{array}{l}\text { Santavirta et al., } \\
\quad 1991\end{array}$ & Retrospective & 38 & $56(35-77)$ & $30: 8$ & - & Posterior fusion & $\begin{array}{l}\text { AAS in } 27 ; \mathrm{BI} \text { in } 2 \text {; SAS } \\
\text { in } 10\end{array}$ \\
\hline Chan et al., 1992 & Retrospective & 19 & 54.2 & $14: 5$ & 60 & $\begin{array}{l}\text { Posterior fusion (occipitocervical in } \\
\text { 16; atlantoaxial in 20) }\end{array}$ & AAS \\
\hline Eyres et al., 1998 & Retrospective & 26 & 64.5 & $21: 5$ & - & Posterior fusion & $\begin{array}{l}\text { AAS in 13; SAS in } 7 \text {; BI in } \\
6 \text {; AAS \& SAS in } 4\end{array}$ \\
\hline $\begin{array}{l}\text { Christensson et al., } \\
2000\end{array}$ & Retrospective & 82 & $65(36-81)$ & $61: 21$ & 7 & $\begin{array}{l}\text { Posterior fusion (atlantoaxial in } 53 \& \\
\text { occipitocervical in 19) }\end{array}$ & $\begin{array}{l}\text { AAS in } 66 \text {; SAS in } 27 ; \mathrm{BI} \\
\quad \text { in } 10\end{array}$ \\
\hline Omura et al., 2002 & Retrospective & 11 & $61.5(46-74)$ & $11: 0$ & $39.8(14-62)$ & Posterior fusion (occipitocervical) & $\begin{array}{l}\text { AAS in } 1 \text {; SAS in } 1 \text {; AAS, } \\
\text { SAS \& BI in } 3\end{array}$ \\
\hline Tanaka et al., 2005 & Retrospective & 26 & 53 & $6: 20$ & - & Posterior fusion (atlantoaxial) & AAS \\
\hline Clarke et al., 2006 & Retrospective & 51 & 61 & $40: 11$ & 96 & $\begin{array}{l}\text { Posterior fusion (atlantoaxial in 31; } \\
\text { subaxial in 17; occipitocervical } \\
\text { in } 3 \text { ) }\end{array}$ & $\begin{array}{l}\text { AAS in } 33 ; \text { SAS in } 8 ; \mathrm{BI} \\
\text { in } 2\end{array}$ \\
\hline $\begin{array}{l}\text { Ronkainen et al., } \\
2006\end{array}$ & Retrospective & 86 & 61.8 & - & $90(60-120)$ & $\begin{array}{l}\text { Posterior fusion (atlantoaxial in 78; } \\
\text { occipitocervical in 3) }\end{array}$ & AAS \\
\hline Kotil, 2012 & Retrospective & 15 & 57.4 & $6: 9$ & - & Posterior fusion & $\begin{array}{l}\text { AAS in 2; SAS in 8; AAS } \\
\quad \& \text { BI in } 5\end{array}$ \\
\hline $\begin{array}{l}\text { Miyamoto et al., } \\
2013\end{array}$ & Retrospective & 118 & 61.0 & $86: 32$ & $64(1-180)$ & $\begin{array}{l}\text { Posterior fusion (atlantoaxial in 28; } \\
\text { occipitocervical in 41); anterior } \\
\text { fusion in } 5\end{array}$ & $\mathrm{BI}, \mathrm{AAS}, \mathrm{BI}$ \\
\hline
\end{tabular}

* Gray shading indicates studies that were included in the pooled data analysis.

val (AADI) and posterior atlantodental interval (PADI). AADI and PADI measure the space available between spinal cord and the vertebra ventrally and posteriorly. Boden et al., have observed that a PADI of at least $10 \mathrm{~mm}$ always resulted in improvement of 1 neurological class, ${ }^{3}$ and hence many spine experts have advocated surgery when PADI is less than $14 \mathrm{~mm}$ in atlantoaxial subluxation. In the same report, PADI was proven superior as both a diagnostic and a prognostic parameter when AADI failed to be as useful as PADI. On the other hand, subaxial canal diameter, which is the space available for the spinal cord below the axis, was shown to have similar finding $(<14$ $\mathrm{mm}$ ) as a useful prognostic factor in subaxial subluxation. Furthermore, vertical subluxation, as in basilar invagination, has a worse prognosis and poor motor recovery compared with horizontal subluxation. Despite the high rate of morbidity resulting from surgery, the fear of potentially life-threatening events eventually prompts most spinal surgeons to perform surgery.

\section{Discussion}

The optimal surgical approach in the treatment of the rheumatoid spine remains a controversy in spine surgery. To our knowledge, there have been only 2 studies that included analyses of type of spine surgery (anterior vs posterior) in RA patients. ${ }^{7,30}$ Casey et al. ${ }^{7}$ reported the results of a prospective study involving 116 patients with vertical translocation, a Ranawat neurological classification of at least Class II, and a mean postoperative follow-up of 62.3 months. The choice of anterior-posterior combination vs posterior-only surgery was made based on whether the compression was predominantly anterior or posterior and if the translocation was reducible with traction. A transoral procedure was carried out in 67 cases (57.8\%). Neurological improvement was seen in $46 \%$ of the patients treated with a posterior approach group and $44 \%$ of those treated with an anterior approach group. However, the difference of 2 percentage points was not statistically significant. In 


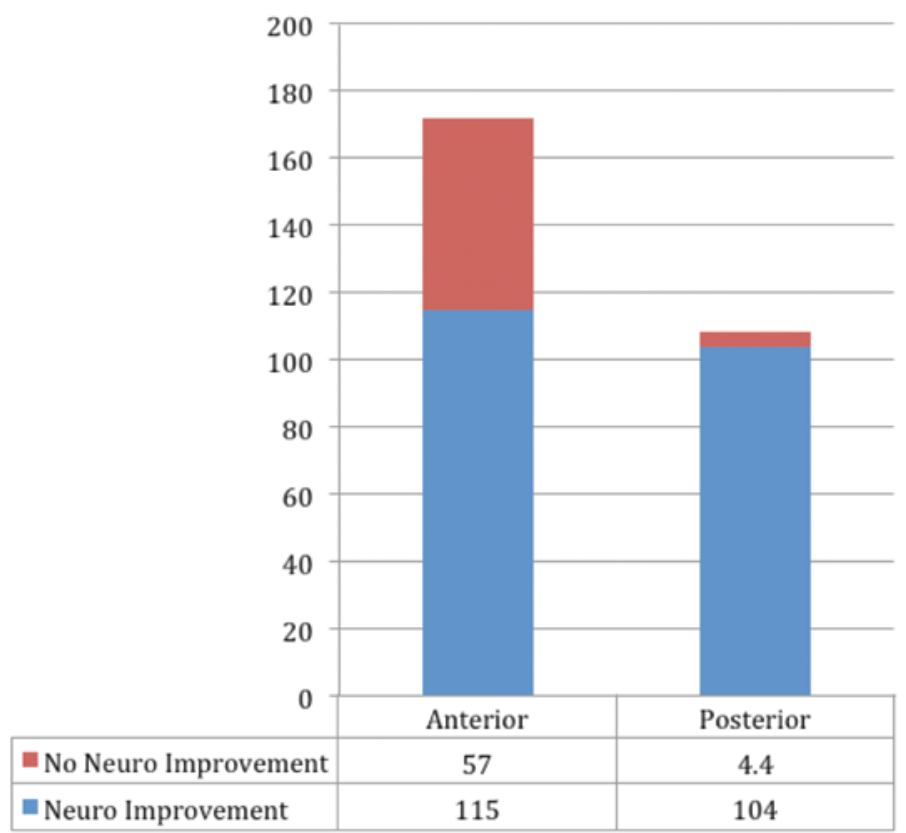

No Neuro Improvement

Neuro Improvement

FIG. 2. Bar diagram summarizing the comparative neurological improvement in patients treated with anterior versus posterior approaches. About $68 \%$ of patients who underwent an anterior approach demonstrated neurological improvement in comparison with $98 \%$ of patients who underwent a posterior approach. Neuro $=$ neurological.

the same study, the authors also showed higher incidence of chest infection in the anterior-approach group, but the association was not statistically significant. Nannapaneni and colleagues ${ }^{30}$ examined surgical outcome in patients with very poor preoperative neurological status (Ranawat Class IIIB) and a mean follow-up of 39 months. All the patients underwent halo placement before surgery, and if their subluxation was reducible, they had the posterioronly surgery. However, only 2 of the patients with reduc- ible subluxations had basilar invagination. The influence of different surgical approaches on clinical outcome was not found to be statistically significant. Several articles have shown that pannus regression is also possible with posterior stabilization despite anterior location of the pannus. ${ }^{20,23,24,37,41,42}$

\section{Transoral}

Fang and Ong were among the first to use a transoral

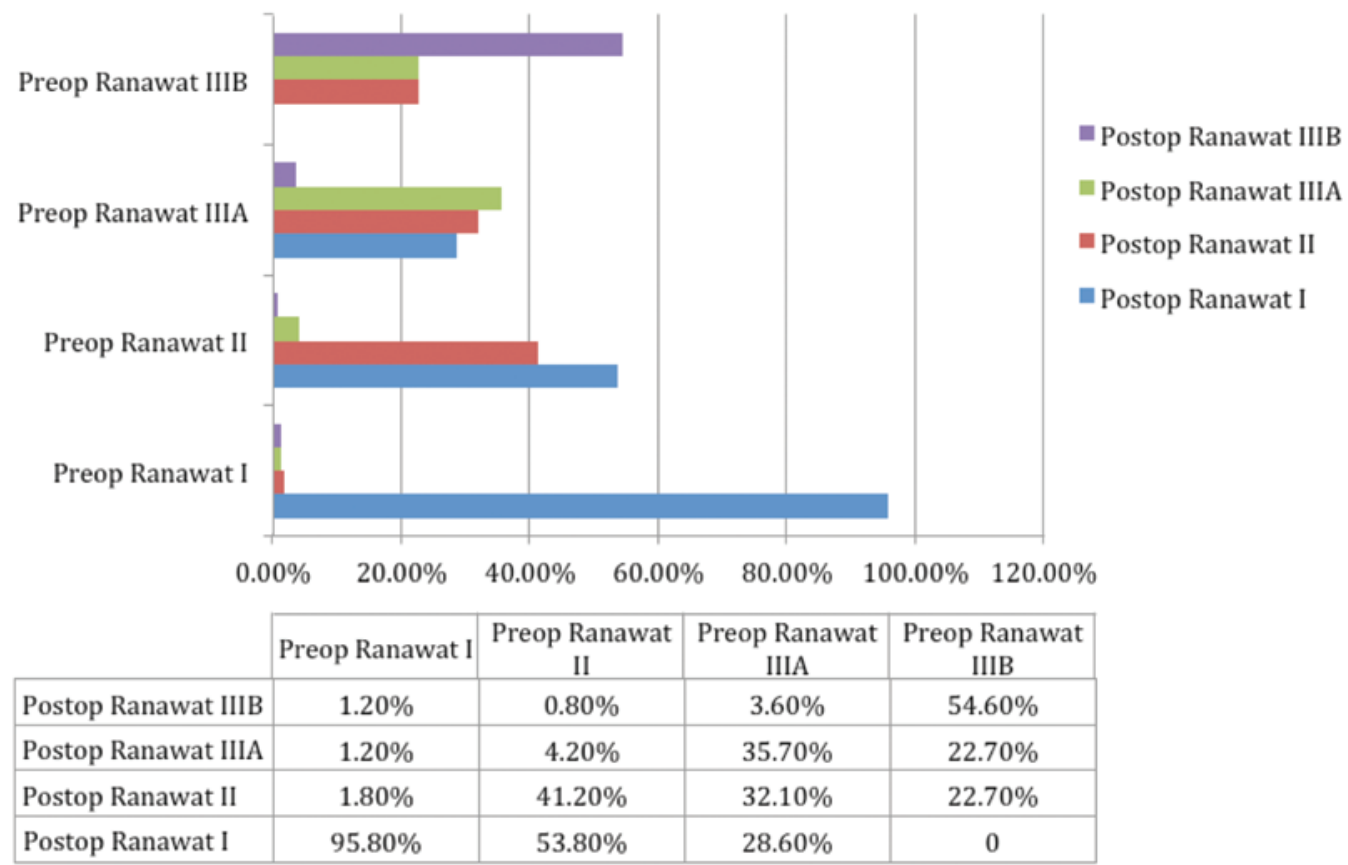

FIG. 3. Analysis of the pooled data demonstrating the neurological outcome based on the Ranawat criteria for the anterior approach. It is easily appreciated that the more severe the disease is, the less is the possibility of improvement. 


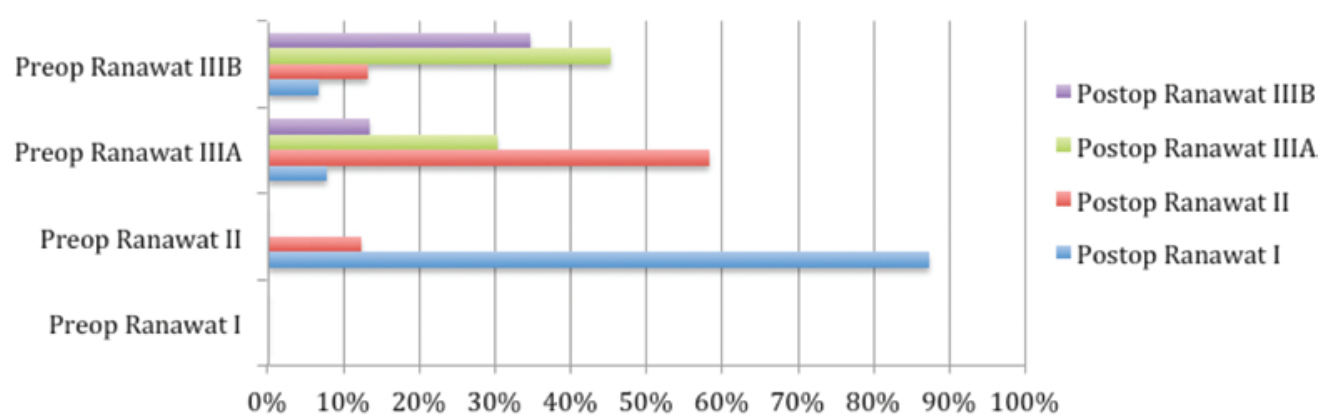

\begin{tabular}{|l|c|c|c|c|}
\cline { 2 - 5 } \multicolumn{1}{c|}{} & $\begin{array}{c}\text { Preop Ranawat } \\
\text { I }\end{array}$ & $\begin{array}{c}\text { Preop Ranawat } \\
\text { II }\end{array}$ & $\begin{array}{c}\text { Preop Ranawat } \\
\text { IIIA }\end{array}$ & $\begin{array}{c}\text { Preop Ranawat } \\
\text { IIIB }\end{array}$ \\
\hline " Postop Ranawat IIIB & 0 & 0 & $13.40 \%$ & $34.70 \%$ \\
\hline " Postop Ranawat IIIA & 0 & 0 & $30.50 \%$ & $45.30 \%$ \\
\hline " Postop Ranawat II & 0 & $12.50 \%$ & $58.40 \%$ & $13.30 \%$ \\
\hline " Postop Ranawat I & 0 & $87.50 \%$ & $7.90 \%$ & $6.70 \%$ \\
\hline
\end{tabular}

FIG. 4. Analysis of the pooled data demonstrating the neurological outcome based on the Ranawat criteria for the posterior approach. Ranawat scores have shown better improvement in the posterior approach.

approach in treating atlantoaxial instability. ${ }^{17}$ It can be categorized into 3 different types: 1) transoral-transpalatal approach, 2) transoral-transpharyngeal or standard transoral, and 3) transmandibular with split. The standard transoral approach provides exposure from the lower third of the clivus to C-2. Due to the common rheumatoid spine pathology at $\mathrm{CVJ}$, the standard transoral approach has been mainly employed in direct ventral decompression from the mass effect exerted by the pannus and odontoid peg compression on the spinal cord at the CVJ. The decompression is achieved mainly via odontoidectomy, and posterior fixation is carried out on the same day to correct the craniocervical instability resulting from the procedure. Choi et al. ${ }^{9}$ described a decreasing trend in the use of transoral procedures in a series of 479 patients over 3 decades. This might be explained by the evolution of medical treatment (i.e., disease-modifiying antirheumatic drugs) and the advancement of surgical approaches, especially the dorsal route of fixation and fusion.

\section{Endoscopy}

More recently, endoscopic transnasal procedures have gained popularity for odontoid resection. These minimally invasive techniques address various limitations of open transoral approaches. Avoidance of a transmaxillary procedure is probably the major advantage, as the splitting of the palate is known to be associated with a high incidence of morbidity. ${ }^{9}$ However, Choi et al. pointed out the relatively high incidence of CSF leak associated with the endoscopic technique (22\%-25\%) compared with the conventional one (1.3\%).

\section{Atlantoaxial Fusion}

Historically, a posterior fusion mainly comprised of various wiring construct techniques, which include Gallie, Brooks, and Sonntag-Dickman techniques. During the 1st decades of the 21st century, there has been a trend of increasing use of transarticular screws in correcting atlan-

TABLE 3. Complications following an anterior approach

\begin{tabular}{|c|c|c|c|c|c|c|c|c|}
\hline Authors \& Year & Sepsis & Respiratory* & Cervical Infection & Cardiac Failure/MI & Dysphagia & CSF Leak & Pseudarthrosis & SAS/ASD \\
\hline Ranawat et al., 1979 & $7.1 \%$ & $7.1 \%$ & NR & NR & NR & NR & $4 / 28$ & 14.3 \\
\hline Thompson \& Meyer, 1985 & NR & $8.3 \%$ & NR & NR & NR & NR & $8.3 \%$ & NR \\
\hline Larsson \& Toolanen, 1986 & NR & $2.9 \%$ & NR & NR & NR & NR & $14 \%$ & NR \\
\hline Clark et al., 1989 & NR & $7.3 \%$ & $7.3 \%$ & $2.4 \%$ & NR & NR & NR & NR \\
\hline Santavirta et al., 1991 & $5.3 \%$ & $2.6 \%$ & $2.6 \%$ & $7.9 \%$ & NR & NR & NR & NR \\
\hline Chan et al., 1992 & $5.3 \%$ & $5.3 \%$ & $5.3 \%$ & $5.3 \%$ & $5.3 \%$ & NR & NR & NR \\
\hline Eyres et al., 1998 & NR & NR & $3.8 \%$ & NR & NR & NR & NR & NR \\
\hline Christennson et al., 2000 & NR & NR & $3.7 \%$ & $1.2 \%$ & NR & $1.2 \%$ & NR & NR \\
\hline Omura et al., 2002 & NR & NR & $9.1 \%$ & NR & NR & NR & NR & NR \\
\hline Tanaka et al., 2005 & NR & 0 & $7.7 \%$ & NR & NR & NR & NR & NR \\
\hline Clarke et al., 2006 & NR & NR & NR & NR & NR & NR & NR & $39.3 \%$ \\
\hline Ronkainen et al., 2006 & NR & $2.3 \%$ & NR & NR & NR & NR & NR & NR \\
\hline Miyamoto et al., 2013 & NR & NR & NR & NR & NR & NR & $4.3 \%$ & NR \\
\hline
\end{tabular}

$\mathrm{ASD}=$ adjacent segment disease; $\mathrm{MI}=$ myocardial infarction; $\mathrm{NR}=$ not reported.

* Pneumonia, respiratory insufficiency. 
TABLE 4. Complications following a posterior approach

\begin{tabular}{|c|c|c|c|c|c|c|c|}
\hline Author \& Year & $\begin{array}{l}\text { Pharyngeal } \\
\text { Infection }\end{array}$ & $\begin{array}{l}\text { Cervical Wound } \\
\text { Infection }\end{array}$ & $\begin{array}{c}\text { VA Occlusion w/ Brainstem } \\
\text { Stroke }\end{array}$ & Respiratory* & CSF Leak & Meningitis & Septicemia \\
\hline Menezes et al., 1985 & 0 & NR & NR & NR & NR & NR & NR \\
\hline Crockard et al., 1986 & 0 & NR & NR & NR & NR & NR & NR \\
\hline Menezes \& VanGilder, 1988 & $7.0 \%$ & NR & NR & NR & NR & NR & NR \\
\hline Spetzler et al., 1988 & NR & NR & $7.7 \%$ & $7.7 \%$ & NR & NR & NR \\
\hline Hadley et al., 1989 & NR & $4.7 \%$ & $4.7 \%$ & $9.5 \%$ & 0 & NR & NR \\
\hline Crockard et al., 1990 & NR & NR & NR & $5.9 \%$ & $8.8 \%$ & $2.9 \%$ & $1.4 \%$ \\
\hline Casey et al., 1997 & $4.3 \%$ & $0.9 \%$ & NR & $19.8 \%$ & NR & $2.6 \%$ & NR \\
\hline Nannapanenei et al., 2005 & & & $3.1 \%$ & $12.5 \%$ & & & \\
\hline Choi \& Crockard, 2013 & 0 & $2.1 \%$ & NR & $10.8 \%$ & 0 & $0.5 \%$ & $1.1 \%$ \\
\hline
\end{tabular}

$\mathrm{VA}=$ vertebral artery.

* Pneumonia, pulmonary embolus, atelectasis.

TABLE 5. Results of multivariate analysis*

\begin{tabular}{lcc}
\hline \multicolumn{1}{c}{ Variable } & $\begin{array}{c}\text { Adjusted OR for } \\
\text { Neurological Improvement }\end{array}$ & $\mathrm{p}$ Value \\
\hline Anterior vs posterior & 0.584 & 0.445 \\
\hline Sex (female) & 21.250 & 0.001 \\
\hline Age (>70 yrs) & 1.563 & 0.445 \\
\hline Preop Ranawat class (Class III) & 1.471 & 0.391 \\
\hline Follow-up (>5 yrs) & 13.106 & 0.003 \\
\hline
\end{tabular}

* Odd ratios for neurological improvement, estimated significance for anterior versus posterior, sex, mean age, preoperative neurological status, and length of follow-up in the 121 cases included in the pooled data analysis. toaxial subluxation. Unlike the conventional wiring techniques, the placement of transarticular screws from the pars interarticularis of C-2 into the lateral mass of C-1 can provide immediate rigid internal fixation.

\section{Occipitocervical Fusion}

Extension of fusion or fixation to the occipital bone is commonly carried out in patients with basilar invagination. This is the type of fusion that has always been employed following anterior odontoidectomy to correct the secondary instability.

\section{Limitations of This Study}

The major limitation of our analysis was the small number of qualifying studies that included long-term followup. In addition, our analysis was based almost entirely on

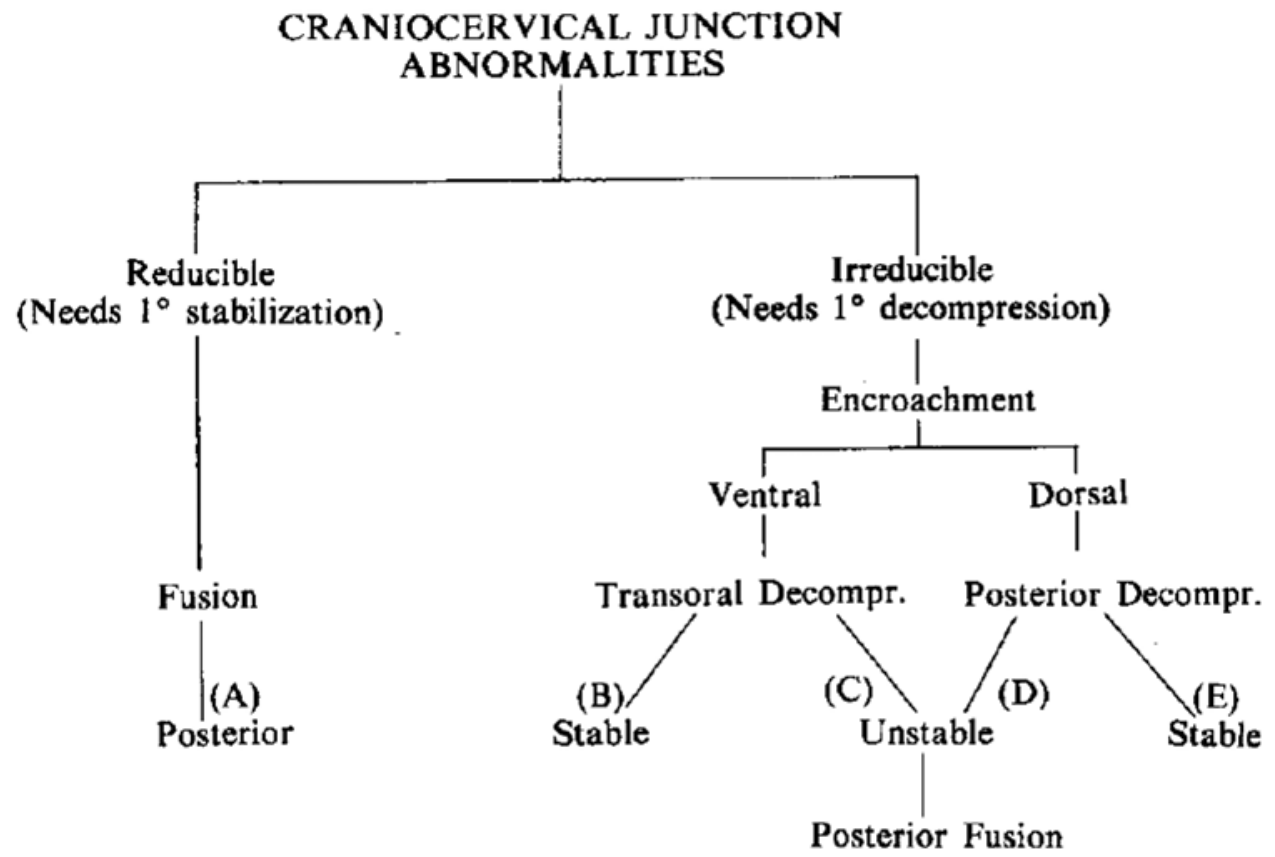

FIG. 5. Treatment algorithm of Menezes et al., which assists the surgeon in decision making depending on the physical examination and radiological findings and the reducibility of the deformity. Decompr. $=$ decompression; $1^{\circ}=$ primary. From Menezes et al..$^{28}$ Published with permission. 
retrospective studies. It included only 1 prospective study, and we did not find any randomized clinical trial in the current literature.

\section{Conclusions}

Numerous factors, including reducibility of the deformity, the direction of greatest compression, preoperative neurological status, and the patient's age, need to be considered before deciding to carry out either approach. In 1980, Menezes et al. proposed an algorithm (Fig. 5) for surgical treatment of CVJ pathology based on most of the factors mentioned..$^{28}$ Our findings reinforced the principle of management as illustrated in the algorithm and also added several extra factors (i.e., preoperative neurological status) for consideration when choosing either approach.

In our analysis, we showed that $66 \%$ of those with Class IIIB myelopathy improved to at least 1 class above in the anterior-approach group during postoperative follow-up while compared with $46 \%$ in the posterior-approach group. There was no case in either group in which a patient's condition improved to Class I. Patients with a Ranawat Class IIIB score have the worst prognosis and outcome.

As far as neurological improvement is concerned, overall, statistics demonstrated the superiority of the posterior approach in patients whose subluxation is reducible. Hence, it would be best to avoid an anterior approach unless it is indicated, as in those cases in which a subluxation is not reducible, even with traction. We recommend that surgical decision making in managing CVJ complications of RA should be based on the correlation between the clinical picture and radiological findings in individual patients, and we hope that our results will be helpful in that process.

\section{References}

1. Aggarwal A, Kulshreshtha A, Chaturvedi V, Misra R: Cervical spine involvement in rheumatoid arthritis: prevalence and relationship with overall disease severity. J Assoc Physicians India 44:468-471, 1996

2. Bland JH, Davis PH, London MG, Vanbuskirk FW, Duarte CG: Rheumatoid arthritis of cervical spine. Arch Intern Med 112:892-898, 1963

3. Boden SD, Dodge LD, Bohlman HH, Rechtine GR: Rheumatoid arthritis of the cervical spine. A long-term analysis with predictors of paralysis and recovery. J Bone Joint Surg Am 75:1282-1297, 1993

4. Cabot A, Becker A: The cervical spine in rheumatoid arthritis. Clin Orthop Relat Res (131):130-140, 1978

5. Casey AT, Crockard HA, Bland JM, Stevens J, Moskovich R, Ransford A: Predictors of outcome in the quadriparetic nonambulatory myelopathic patient with rheumatoid arthritis: a prospective study of 55 surgically treated Ranawat class IIIb patients. J Neurosurg 85:574-581, 1996

6. Casey AT, Crockard HA, Bland JM, Stevens J, Moskovich $\mathrm{R}$, Ransford AO: Surgery on the rheumatoid cervical spine for the non-ambulant myelopathic patient-too much, too late? Lancet 347:1004-1007, 1996

7. Casey AT, Crockard HA, Stevens J: Vertical translocation. Part II. Outcomes after surgical treatment of rheumatoid cervical myelopathy. J Neurosurg 87:863-869, 1997

8. Chan DP, Ngian KS, Cohen L: Posterior upper cervical fusion in rheumatoid arthritis. Spine (Phila Pa 1976) 17:268272, 1992

9. Choi D, Crockard HA: Evolution of transoral surgery: three decades of change in patients, pathologies, and indications. Neurosurgery 73:296-304, 2013

10. Christensson D, Säveland H, Rydholm U: Cervical spine surgery in rheumatoid arthritis. A Swedish nation-wide registration of 83 patients. Scand J Rheumatol 29:314-319, 2000

11. Clark CR, Goetz DD, Menezes AH: Arthrodesis of the cervical spine in rheumatoid arthritis. J Bone Joint Surg Am 71:381-392, 1989

12. Clarke MJ, Cohen-Gadol AA, Ebersold MJ, Cabanela ME: Long-term incidence of subaxial cervical spine instability following cervical arthrodesis surgery in patients with rheumatoid arthritis. Surg Neurol 66:136-140, 2006

13. Conlon PW, Isdale IC, Rose BS: Rheumatoid arthritis of the cervical spine. An analysis of 333 cases. Ann Rheum Dis 25:120-126, 1966

14. Crockard HA, Calder I, Ransford AO: One-stage transoral decompression and posterior fixation in rheumatoid atlantoaxial subluxation. J Bone Joint Surg Br 72:682-685, 1990

15. Crockard HA, Pozo JL, Ransford AO, Stevens JM, Kendall BE, Essigman WK: Transoral decompression and posterior fusion for rheumatoid atlanto-axial subluxation. J Bone Joint Surg Br 68:350-356, 1986

16. Eyres KS, Gray DH, Robertson P: Posterior surgical treatment for the rheumatoid cervical spine. Br J Rheumatol 37: 756-759, 1998

17. Fang HSY, Ong GB: Direct anterior approach to the upper cervical spine. J Bone Joint Surg Am 44:1588-1604, 1962

18. Hadley MN, Spetzler RF, Sonntag VKH: The transoral approach to the superior cervical spine. A review of 53 cases of extradural cervicomedullary compression. J Neurosurg 71:16-23, 1989

19. Kerschbaumer F, Kandziora F, Klein C, Mittlmeier T, Starker M: Transoral decompression, anterior plate fixation, and posterior wire fusion for irreducible atlantoaxial kyphosis in rheumatoid arthritis. Spine (Phila Pa 1976) 25:2708-2715, 2000

20. Kolen ER, Schmidt MH: Rheumatoid arthritis of the cervical spine. Semin Neurol 22:179-186, 2002

21. Kotil K: The long time follow-up of craniovertebral junction fixation in patients with rheumatoid arthritis. J Craniovertebr Junction Spine 3:42-46, 2012

22. Laiho K, Belt E, Kauppi M: The cervical spine in mutilant rheumatoid arthritis. Rheumatol Int 20:225-228, 2001

23. Landi A, Marotta N, Morselli C, Marongiu A, Delfini R: Pannus regression after posterior decompression and occipito-cervical fixation in occipito-atlanto-axial instability due to rheumatoid arthritis: case report and literature review. Clin Neurol Neurosurg 115:111-116, 2013

24. Larsson EM, Holtås S, Zygmunt S: Pre- and postoperative MR imaging of the craniocervical junction in rheumatoid arthritis. AJR Am J Roentgenol 152:561-566, 1989

25. Larsson SE, Toolanen G: Posterior fusion for atlanto-axial subluxation in rheumatoid arthritis. Spine (Phila Pa 1976) 11:525-530, 1986

26. Menezes AH, VanGilder JC: Transoral-transpharyngeal approach to the anterior craniocervical junction. Ten-year experience with 72 patients. J Neurosurg 69:895-903, 1988

27. Menezes AH, VanGilder JC, Clark CR, el-Khoury G: Odontoid upward migration in rheumatoid arthritis. An analysis of 45 patients with “cranial settling." J Neurosurg 63:500-509, 1985

28. Menezes AH, VanGilder JC, Graf CJ, McDonnell DE: Craniocervical abnormalities. A comprehensive surgical approach. J Neurosurg 53:444-455, 1980

29. Miyamoto H, Sumi M, Uno K: Outcome of surgery for rheumatoid cervical spine at one institute over three decades. Spine J 13:1477-1484, 2013

30. Nannapaneni R, Behari S, Todd NV: Surgical outcome in rheumatoid Ranawat Class IIIb myelopathy. Neurosurgery 56:706-715, 2005 
31. Omura K, Hukuda S, Katsuura A, Saruhashi Y, Imanaka T, Imai S: Evaluation of posterior long fusion versus conservative treatment for the progressive rheumatoid cervical spine. Spine (Phila Pa 1976) 27:1336-1345, 2002

32. Pellicci PM, Ranawat CS, Tsairis P, Bryan WJ: A prospective study of the progression of rheumatoid arthritis of the cervical spine. J Bone Joint Surg Am 63:342-350, 1981

33. Ranawat CS, O'Leary P, Pellicci P, Tsairis P, Marchisello P, Dorr L: Cervical spine fusion in rheumatoid arthritis. J Bone Joint Surg Am 61:1003-1010, 1979

34. Ronkainen A, Niskanen M, Auvinen A, Aalto J, Luosujärvi $\mathrm{R}$ : Cervical spine surgery in patients with rheumatoid arthritis: longterm mortality and its determinants. J Rheumatol 33:517-522, 2006

35. Santavirta S, Konttinen YT, Laasonen E, Honkanen V, Antti-Poika I, Kauppi M: Ten-year results of operations for rheumatoid cervical spine disorders. J Bone Joint Surg Br 73:116-120, 1991

36. Spetzler RF, Hadley MN, Sonntag VK: The transoral approach to the anterior superior cervical spine. A review of 29 cases. Acta Neurochir Suppl (Wien) 43:69-74, 1988

37. Stiskal MA, Neuhold A, Szolar DH, Saeed M, Czerny C, Leeb B, et al: Rheumatoid arthritis of the craniocervical region by MR imaging: detection and characterization. AJR Am J Roentgenol 165:585-592, 1995

38. Tanaka N, Sakahashi H, Hirose K, Ishima T, Takahashi H, Ishii S: Results after 24 years of prophylactic surgery for rheumatoid atlantoaxial subluxation. J Bone Joint Surg Br 87:955-958, 2005

39. Thompson RC Jr, Meyer TJ: Posterior surgical stabilization for atlantoaxial subluxation in rheumatoid arthritis. Spine (Phila Pa 1976) 10:597-601, 1985

40. Zikou AK, Alamanos Y, Argyropoulou MI, Tsifetaki N, Tsampoulas C, Voulgari PV, et al: Radiological cervical spine involvement in patients with rheumatoid arthritis: a cross sectional study. J Rheumatol 32:801-806, 2005

41. Zoma A, Sturrock RD, Fisher WD, Freeman PA, Hamblen DL: Surgical stabilisation of the rheumatoid cervical spine. A review of indications and results. J Bone Joint Surg Br 69:8-12, 1987

42. Zygmunt $S$, Säveland $H$, Brattström $H$, Ljunggren B, Larsson EM, Wollheim F: Reduction of rheumatoid periodontoid pannus following posterior occipito-cervical fusion visualised by magnetic resonance imaging. Br J Neurosurg 2:315-320, 1988

\section{Author Contributions}

Conception and design: Madhavan. Acquisition of data: Chieng. Analysis and interpretation of data: Madhavan, Chieng. Drafting the article: Chieng. Critically revising the article: Madhavan. Reviewed submitted version of manuscript: Vanni. Statistical analysis: Madhavan. Administrative/technical/material support: Vanni. Study supervision: Madhavan, Vanni.

\section{Correspondence}

Karthik Madhavan, Department of Neurological Surgery, University of Miami Miller School of Medicine, Lois Pope Life Center, 2nd Fl., 1095 N.W. 14th Terrace (D4-6), Miami, FL 33136. email: drkarthik19@gmail.com. 